\title{
THE INFLUENCE OF ORGANIZATIONAL CULTURE AND ORGANIZATIONAL COMMITMENT ON EMPLOYEE PERFORMANCE
}

\author{
(Study in PT Pelayaran Samudera Selatan Jakarta) \\ Herwan Abdul Muhyi \\ (Dosen Administrasi Niaga FISIP UNPAD)
}

\begin{abstract}
Abstrak
Organizational culture and organizational commitment are the two factors that related to unoptimal employee performance The purpose of this research is to know, firstl; the implementation of organizational culture,organizational commitment, employee performance; and secondly, the influence of organizational culture and organizational commitment on the employee performancet. Variables of this research consist of organizational culture $(X 1)$, organizational commitment with subvariables; affective commitment $(X 2)$, continuance commitmen (X3), normative commitment $(X 4)$. and employee performance $(Y)$.

This research use explanatory method to explain causal relation among variables through hipotetical assessment. The population of the research is all employees worked in PT Pelayaran Samudera Selatan Jakarta. All of the employees became respondens of this research. The indicators of organizational culture are based on the Stephen Robbins Theory, organizational commitment indicators adoptedfrom Meyer and Allen Theory, and employee performance based on Bernardin and Russel theory.

Generally, it is found that the perception to organizational culture, organizational commitment and employee performance of PT pelayaran Samudera Selatan can be categorized as good. From the path analyses, it is found that the organizational culture and organizational commitment has a strong positive impact either partially or simultancy on the employee performance.
\end{abstract}

Keywords: Organizational Culture, Commitment and Performance

\section{PENDAHULUAN}

Persaingan antar perusahaan pelayaran, khususnya di Indonesia merupakan suatu tantangan besar yang harus disikapi dan dihadapi dengan kemampuan manajemen perusahaan yang handal. Apabila ini dapat dilakukan maka perusahaan akan mendapatkan keunggulan bersaing (competitive adventage).

PT Pelayaran Samudera Selatan, merupakan salah satu perusahaan yang bergerak dalam bidang jasa pelayaran. Perusahaan ini melayani perusahaan-perusahaan yang ingin mengekspor maupun mengimpor barang. Produk perusahaan ini berupa penyewaan kontainer dan kapal sesuai dengan pelabuhan di negara yang dituju oleh konsumen.

PT Pelayaran Samudera Selatan (PSS) merupakan Perusahaan Indonesia yang berdiri pada tahun 1990. Perusahaan ini merupakan agen (agency) dari Pacific International Line (PIL) dan Advance Container Lines (ACL). Kedua prinsipal ini berkedudukan di Singapura.
$\mathrm{Di}$ Indonesia, PIL dan ACL ini mengoperasikan enam kapal yang berkapasitas 800 sampai dengan 1200 TEUs setiap kapal. PIL dan ACL mempercayakan PT Samudera Selatan sebagai satu-satunya agen pelayaran untuk negara Indonesia (shipping line).

Dewasa ini, perusahaan pelayaran dihadapkan pada persaingan yang begitu ketat, karena banyak perusahaan-perusahaan yang bergerak di bidang jasa pelayaran (shipping line). Selain itu persaingan juga semakin ramai dengan banyaknya forwarder yang menawarkan jasa yang sama kepada konsumen.

Kondisi demikian, menuntut PT Pelayaran Samudera Selatan sebagai organisasi yang berusaha mencapai keuntungan yang optimal dan keberlangsungan hidupnya, harus mampu menjawab segala tantangan perubahan dan persaingan bisnis yang semakin ketat. Berbagai upaya dalam rangka menjawab tantangan tersebut diharapkan dapat meningkatkan adaptabilitas dan keunggulan bersaing (competitive advantage). 
Salah satu upaya besar yang harus dilakukan perusahaan adalah mengoptimalkan sumber daya manusia yang dimiliki sebagai salah satu sumber daya perusahaan yang sangat penting. Begitu pentingnya sumber daya manusia bagi perusahaan, dikemukakan oleh Stoner (1989: 329) "The most important of organization are its human resources, the people who supply the organization with their work, creativity, talent and drive." Pendapat Stoner tersebut menjelaskan betapa besar kontribusi manusia terhadap organisasi.

Peran yang sangat besar dari karyawan sebagai sumber daya terpenting tersebut, harus diiringi dengan kinerja atau performa yang optimal. Kinerja optimal yang dilakukan karyawan akan berpengaruh terhadap kinerja perusahaan secara keseluruhan.

Peningkatan kinerja karyawan mutlak dilakukan oleh perusahaan. Berbagai strategi dapat dilakukan perusahaan dalam upaya melejitkan kinerja karyawannya.

Dalam menyusun strategi melejitkan kinerja tersebut, perusahaan dihadapkan pada berbagai faktor yang harus dianalisis. Salah satu faktor penting yang harus dianalisi tersebut adalah budaya perusahaan.

Strategi yang diterapkan dalam perusahaan, harus diiringi dengan budaya organisasi yang optimal, yakni budaya yang dapat mendukung pencapaian tujuan organisasi. Budaya yang optimal adalah budaya yang dapat mendukung dengan baik visi dan strategi perusahaan yang merupakan bagian di dalamnya (Wheelen dan Hunger, 2000:215).

Kecermatan karyawan dalam beberapa bidang terutama bidang operation dan dokumen ekspor belum begitu baik, Hal ini terlihat terdapat kecerobohan dan kekurang telitian pegawai dalam melaksanakan pekerjaan. Hal ini menunjukkan perhatian ke rincian (Robbins:2001), belum optimal.

Nilai budaya perusahaan yang masih belum optimal terutama mengenai perhatian perusahaan terhadap karyawan. Hal ini ditunjukkan dengan keluhan karyawan mengenai kesejahteraan dan tunjangan-tunjangan yang menurut beberapa karyawan kurang sepadan dengan pekerjaan yang dijalaninya.

Perusahaan, masih memiliki kelemahan dalam menanamkan budaya kerja tim. Hal ini terlihat dengan adanya kejadian saling menyalahkan antara salah satu staf marketing dengan bagian dokumen. Seorang staf marketing menerima komplain dari shipper, dan staf marketing tersebut menyalahkan kepada bagian dokumen.

PT Pelayaran Samudera Selatan, seyogyanya mengintrospeksi budaya yang selama ini berlangsung di perusahaan. Budaya perusahaan harus dikondisikan agar kondusif terhadap aktivitas perusahaan. Budaya perusahaan yang kondusif, akan menimbulkan komitmen yang kuat dari karyawan terhadap perusahaan. Budaya mempermudah timbulnya komitmen pada sesuatu yang lebih luas daripada kepentingan diri individual seseorang (Robbins, 2001: 515)

Tanpa ada komitmen karyawan terhadap perusahaan, rencana-rencana dan target perusahaan akan sulit terealisir. Komitmen karyawan pada perusahaan dapat meminimalisir turnover dan tingkat absensi serta diharapkan dapat melejitkan kinerja mereka. Penelitian terdahulu maupun terkini, mendukung hubungan positif antara komitmen organisasi dan keluaran yang diharapkan, seperti kinerja yang tinggi, turnover yang rendah dan tingkat absensi yang rendah (Luthan, 2002: 237).

Kesalahan destinasi pengiriman kontainer, pernah terjadi. Setelah ditelusuri ternyata kesalahan dilakukan oleh pihak eksternal, yakni pihak bongkar muat. Kondisi ini mungkin tidak akan terjadi apabila karyawan memiliki upaya keras untuk selalu melakukan konfirmasi dengan pihak bongkar muat. Selain hal tersebut, beberapa karyawan tidak melanjutkan karirnya pada perusahaan. Hal ini menunjukkan bahwa ada kelemahan dalam hal komitmen karyawan terhadap organisasi.

\section{TINJAUAN TEORITIS}

Schein (2002) mengatakan bahwa sekarang ini budaya organisasi memiliki arti yang lebih penting dibandingkan dahulu. Meningkatnya iklim kompetisi, globalisasi, merjer, akuisisi, aliansi, dan perkembangan dunia pekerjaan yang bervariasi.

Ketertarikan para peneliti melakukan penelitian terhadap budaya organisasi menunjukkan semakin pentingnya peranan budaya organisasi. Para peneliti melakukan studi terhadap budaya organisasi dikaitkan dengan berbagai variabel 


\section{StrategiC}

seperti; kepuasan kerja, komitmen organisasi, kinerja karyawan, kinerja perusahaan, dan berbagai variabel lainnya.

Salah satu faktor yang menjadi ciri khas suatu organisasi yang membedakan organisasi tersebut dengan organisasi lainnya adalah budaya yang dianut oleh organisasi yang bersangkutan. Budaya organisasi merupakan nilai-nilai yang memiliki makna bersama yang disepakati dalam kelangsungan hidup organisasi. Robbins (2001: 510) : "Organizational culture refers to a system of shared meaning held by members that distinguishes the organization from other organizations".

Setiap anggota organisasi pada umumnya dilatar belakangi oleh budaya yang mempengaruhi mereka dalam berperilaku. Budaya menuntun individu untuk berperilaku dan memberi petunjuk pada mereka mengenai apa yang boleh dilakukan dan tidak boleh dilakukan.

Pada kenyataannya, seringkali ditemui nilai-nilai karyawan tertentu yang dilakukan seharihari dan menjadi kebiasaan. Hal ini dipengaruhi oleh tingkat pemahaman atau persepsi karyawan terhadap nilai-nilai yang berlaku serta menjadi acuan karyawan dalam melaksanakan pekerjaan.

Nilai-nilai yang dipersepsikan dan dijadikan pedoman oleh karyawan tersebut secara keseluruhan menjadi budaya atau kepribadian organisasi itu (Robbins, 2001: 307).

Robbins (2001: 510) mengemukakan bahwa budaya organisasi memiliki 7 (tujuh) karakteristik primer yang bersama-sama menangkap hakekat dari suatu budaya organisasi, yaitu : Innovation and risk taking (inovasi dan pengambilan resiko), Attention to detail (perhatian ke rincian), Outcome orientation (orientasi hasil), People orientation (orientasi orang), Team orientation (orientasi tim), Aggresiveness (keagresifan), Stability (kemantapan). Nilai-nilai yang memiliki makna bersama yang dianut oleh karyawan dalam organisasi menjadi budaya organisasi. Budaya organisasi ini akan mempengaruhi penilaian dan persepsi karyawannya terhadap organisasi tempat karyawan tersebut berada. Pada akhirnya budaya yang dianut dalam suatu organisasi akan sangat menentukan sejauhmana komitmen karyawan terhadap organisasi. Robbis (2001: 515$)$ yaitu" Budaya mempermudah timbulnya komitmen pada sesuatu yang lebih luas daripada kepentingan diri individual seseorang".
Dengan nilai-nilai yang dianut oleh organisasi diharapkan dapat memelihara keanggotaan dan eksitensi karyawan, sehingga karyawan memiliki komitmen yang tinggi yang dapat menguntungkan kelangsungan organisasi. Komitmen organisasi sebagai suatu keadaan dimana seorang karyawan memihak pada suatu organisasi tertentu dan tujuan-tujuannya serta berniat memelihara keanggotaan dalam organisasi itu Robbin (2001).

Karyawan yang memiliki komitmen berarti memiliki hubungan emosional dengan organisasi, merasa dirinya sebagai bagian dari organisasi dan terlibat dalam pelaksanaan pekerjaan dalam rangka pencapaian tujuan organisasi. McShane and Glinow (2003) mengemukakan bahwa "Organizational commitment refers to the employee's emotional attachment to, identification with, and involvement in a particular organization".

Untuk mengukur sejauhmana komitmen karyawan terhadap organisasi dapat dilakukan dengan cara melakukan pengukuran dan analisis terhadap dimensi-dimensi: affective commitment (komitmen afektif), continuance commitment (komitmen kontinuens), normative commitment (komitmen normatif). Meyer and Allen dalam Luthan (2002)

Kuat dan lemahnya budaya tergantung dari berbagai macam variabel, termasuk komitmen terhadap tujuan bersama. Lebih jelasnya Kreitner, R., \& Angelo Kinicky (2001) mengemukakan sebagai berikut: "An organization culture maybe strong or weak, depending on variables such as cohesiveness, value consensus, and individual commitment to collective goals".

Selain komitmen organisasi, suatu perusahaan mutlak harus memperhatikan kinerja yang dilakukan oleh seluruh karyawannya. Kinerja merupakan rekaman keluaran pekerjaan karyawansesuai dengan fungsi pekerjaan tertentu selama kurun waktu atau periode tertentu.

Bernardin dan Russel (1998 : 239) menyatakan bahwa : "Performance is defined as the record of outcome produced on a specified job function or activity during a specified time period".

Rekaman keluaran atau outcome ini sangat diperlukan oleh perusahaan untuk mengukur sejauhmana hasil pekerjaan setiap karyawanm. Untuk melakukan pengukuran kinerja karyawan, digunakan enam kriteria primer untuk mengukur kinerja menurut (Bernardin dan Russel; 1998:383), 


\section{StrategiC}

yaitu: Quality, Quantity, Timeliness, Costeffectiveness, Need for supervision, Interpersonal impact.

Kinerja karyawan dipengaruhi oleh berbagai macam variabel, diantaranya budaya dan komitmen organisasi. Hubungan budaya organisasi dan kinerja, diantaranya dikemukakan oleh McShane dan Glinow (2003) :

"...corporate culture is the social glue that bonds people together and makes them feel part of the organizational experiences. Employees are motivated to internalize the organization's dominant culture because it fulfills their need for social identity. This social glue is increasingly important as a way to attract new staf and retain top performer."

Budaya organisasi merupakan perekat sosial yang melingkari rasa kebersamaan orang-orang dan membuat mereka merasa sebagai bagian dari pengalaman organisasi. Karyawan termotivasi untuk menginternalisasikan budaya organisasi yang dominant karena hal tersebut dapat memenuhi keinginan mereka akan identitas social. Perekat social ini menjadi lebih penting sebagai suatu jalan untuk menarik staf baru dan karyawan yang berkinerja tinggi.

Robbins (2001) menjelaskan bahwa budaya organisasi dibentuk dari suatu persepsi subyekif dari karyawan secara keseluruhan berdasarkan pada faktor-faktor seperti toleransi resiko, tekanan pada tim dan dukungan orang. Sebenarnya persepsi keseluruhan ini menjadi budaya atau kepribadian organisasi tersebut. Persepsi yang mendukung atau tidak mendukung ini kemudian mempengaruhi kinerja dan kepuasan kerja karyawan dengan dampak yang lebih besar pada budaya yang lebih kuat.

Keterkaitan antara komitmen organisasi dengan kinerja diantaranya dikemukakan oleh Luthan (2002), baik penelitian terdahulu maupun terkini, mendukung hubungan positif antara komitmen organisasi dan keluaran yang diharapkan, seperti kinerja yang tinggi, turnover yang rendah dan tingkat absensi yang rendah.

Budaya organisasi akan menimbulkan komitmen karyawan terhadap perusahaan, sebaliknya komitmen karyawan terhadap organisasi dapat mempengaruhi budaya organisasi. Kinerja karyawan juga dipengaruhi oleh berbagai variabel diantaranya budaya organisasi dan komitmen organisasi. Berdasarkan kerangka pemikiran di atas, penulis menggambarkan paradigma konseptual penelitian sebagai berikut:

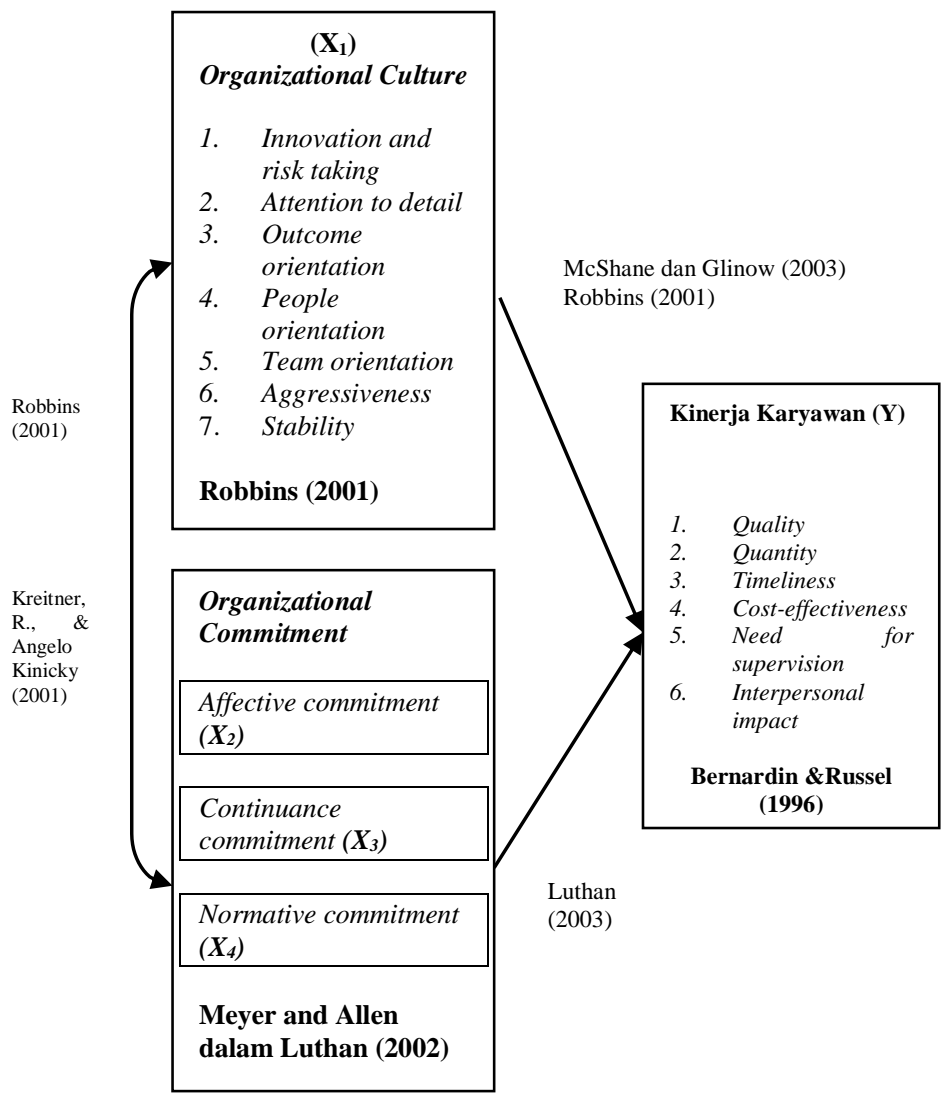

\section{Gambar 2.1: Kerangka Konseptual Penelitian}

Berdasarkan kerangka pemikiran tersebut, maka hipotesis penelitiannya adalah sebagai berikut: "Budaya organisasi dan komitmen organisasi baik secara parsial maupun simultan berpengaruh terhadap kinerja karyawan."

\section{METODE}

Pada penelitian ini digunakan dua jenis bentuk penelitian yaitu penelitian deskriptif dan penelitian verifikatif.

Untuk mengetahui deskripsi budaya organisasi, komitmen organisasi dan kinerja karyawan dilakukan penelitian deskriptif. Sedangkan penelitian verifikatif digunakan untuk menguji hipotesis yang memakai perhitungan-perhitungan statistik (Moh. Nazir, 1998: 63). Penelitian verifikatif digunakan untuk mengetahui besarnya pengaruh budaya organisasi dan komitmen organisasi baik 
secara simultan maupun parsial terhadap kinerja karyawan.

Metode yang digunakan dalam penelitian ini adalah studi serta menggunakan tipe penjelasan (explanatory research), untuk memberikan penjelasan hubungan kausal antara variabelvariabel melalui pengujian hipotesis.

Teknik penarikan sampel yang digunakan adalah Sampling jenuh, yaitu suatu teknik di mana memilih seluruh angota populasi sebagai sample. Sedangkan yang menjadi populasi dalam penelitian ini adalah seluruh karyawan perusahaan yaitu sebanyak 83 orang/karyawan.

Data yang digunakan dalam penelitian ini adalah data primer dan data sekunder. Data primer diperoleh dari karyawan dengan cara menyebarkan kuesioner kepada responden yang dapat mewakili populasi. Kuesioner tersebut disusun berdasarkan skala ordinal yang berpedoman pada Likert Summated Rating.

Dalam penelitian ini pengumpulan data dilakukan dengan menggunakan instrumen kuesioner, oleh karena itu instrumen penelitian ini perlu diuji coba untuk mengetahui validitas dan reliabilitasnya. Dengan menggunakan instrumen yang valid dan reliabel dalam pengumpulan data, maka diharapkan hasil penelitian akan menjadi valid dan reliabel. Jadi instrumen yang valid dan reliabel merupakan syarat mutlak untuk mendapatkan hasil penelitian yang valid dan reliabel (Sugiyono, 1999: 110).

Masri Singarimbun dan Sofyan Effendi (1995: 124) menyatakan bahwa validitas menunjukkan sejauhmana suatu alat ukur dapat mengukur apa yang ingin diukur, sedangkan reliabilitas adalah indeks yang menunjukkan sejauhmana suatu alat pengukur itu dapat dipercaya atau dapat diandalkan.

\section{HASIL PENELITIAN DAN PEMBAHASAN}

Untuk mengukur budaya organisasi PT Pelayaran Samudera Selatan, digunakan tujuh dimensi budaya organisasi. Adapun dimensidimensi tersebuta adlkah: inovasi dan pengambilan resiko, perhatian kerincian, orientasi hasil, orientasi karyawan, orientasi tim, keagresifan dan stabilitas.

Berikut deskripsi budaya organisasi PT Pelayaran Samudera Selatan berdasarkan tanggapan responden terhadap masing-masing dimensi budaya organisasi.
Tabel 4.1 Akumulasi Jawaban Responden Terhadap Budaya Organisasi

\begin{tabular}{|c|l|c|c|}
\hline \hline No. & \multicolumn{1}{|c|}{ Indikator } & $\begin{array}{c}\text { Skor } \\
\text { Total }\end{array}$ & $\begin{array}{c}\text { Rasio } \\
(\%)\end{array}$ \\
\hline \hline 1 & $\begin{array}{l}\text { Inovasi dan pengambilan } \\
\text { resiko }\end{array}$ & 810 & 67,5 \\
\hline 2 & Perhatian kerincian & 927 & 77,3 \\
\hline 3 & Orientasi hasil & 877 & 73,1 \\
\hline 4 & Orientasi orang & 1651 & 68,8 \\
\hline 5 & Orientasi tim & 896 & 74,7 \\
\hline 6 & Keagresifan & 582 & 72,8 \\
\hline 7 & Stabilitas & 763 & 63,6 \\
\hline \hline & Total & 6506 & 71,1 \\
\hline \hline
\end{tabular}

Akumulasi dari seluruh dimensi secara umum menunjukkan bahwa budaya organisasi PT Pelayaran Samudera selatan berada pada kategori tinggi dengan rasio sebesar $71,1 \%$. Dengan demikian dapat dikatakan bahwa budaya organisasi perusahaan selama ini berada pada kondisi baik.

Berdasarkan tanggapan responden, terdapat dua dimensi budaya organisasi, yaitu inovasi dan pengambilan resiko serta stabilitas yang masih termasuk pada kategori sedang. Hal ini menunjukkan bahwa kedua dimensi ini belum berlangsung secara optimal di perusahaan.

Tabel 4.2 Akumulasi Jawaban Responden Terhadap Komitmen Organisasi

\begin{tabular}{|c|l|c|c|}
\hline \hline No. & \multicolumn{1}{|c|}{ Indikator } & $\begin{array}{c}\text { Skor } \\
\text { Total }\end{array}$ & $\begin{array}{c}\text { Rasio } \\
(\%)\end{array}$ \\
\hline \hline 1 & Komitmen Afektif & 1395 & 69,8 \\
\hline 2 & Komitmen Kontinuens & 1663 & 69,3 \\
\hline 3 & Komitmen Normatif & 1157 & 72,3 \\
\hline \multicolumn{2}{r|c}{ Total } & 4215 & 70,4 \\
\hline \hline
\end{tabular}

Secara umum dapat disimpulkan bahwa komitmen pegawai terhadap perusahaan berada pada kategori tinggi. Hal ini menunjukkan bahwa komitmen karyawan terhadap organisasi sudah baik. Namun demikian kalau dilihat dari perolehan skor, hanya sedikit terpaut diatas kategori sedang.

Komitmen normatif, yang berarti karyawan tetap komitmen pada perusahaan karena memang 
sudah seharusnya, mendapatkan angka tertinggi sebesar $72,3 \%$ atau berada pada kategori tinggi. Hal ini berarti sebagian besar karyawan memiliki komitmen kepada perusahaan karena memang seharusnya.

Tabel 4.3 Akumulasi Jawaban Responden Terhadap Kinerja karyawan

\begin{tabular}{|c|c|c|c|}
\hline No. & Indikator & $\begin{array}{l}\text { Skor } \\
\text { Total }\end{array}$ & Rasio (\%) \\
\hline 1 & Kualitas & 578 & 72,3 \\
\hline 2 & Kuantitas & 542 & 67,8 \\
\hline 3 & Ketepatan Waktu & 826 & 68,8 \\
\hline 4 & Efektivitas Biaya & 580 & 72,5 \\
\hline 5 & $\begin{array}{ll}\text { Kebutuhan akan } \\
\text { Supervisi }\end{array}$ & 841 & 70,1 \\
\hline 6 & $\begin{array}{l}\text { Dampak } \\
\text { Interpersonal }\end{array}$ & 863 & 71,9 \\
\hline & Total & 4230 & 70,6 \\
\hline
\end{tabular}

Berdasarkan hasil akumulasi tanggapan responden diperoleh informasi bahwa kondisi kinerja karyawan pada PT Pelayaran Samudera Selatan berada pada kategori tinggi dengan angka akumulasi sebesar $70,6 \%$. Hal ini menunjukkan bahwa selama ini kinerja karyawan sudah baik walaupun masih terdapat beberapa kekurangan.

Dimensi kuantitas dan ketepatan waktu mendapaykan skor terendah, hal ini menunjukkan kedua dimensi ini belum sepenuhnya optimal. Bahkan untuk dimensi kuantitas masih termasuk pada kategori sedang.

Demikian deskreipsi hasil penelitian terkait dengan kondisi budaya organisasi, komitmen organisasi dan kinerja karyawan pada PT Samudera Selatan Jakarta. Untuk mengetahui sejauhmana pengaruh budaya organisasi dan komitmen organisasi terhadap kinerja karyawan, berikut akan diuraikan dengan menggunakan analisis jalur (path analysis).

Setelah dilakukan perhitungan dengan menggunakan analisis jalur, penulis menggambarkan hasil perhitungan dalam model penelitian sebagai berikut:

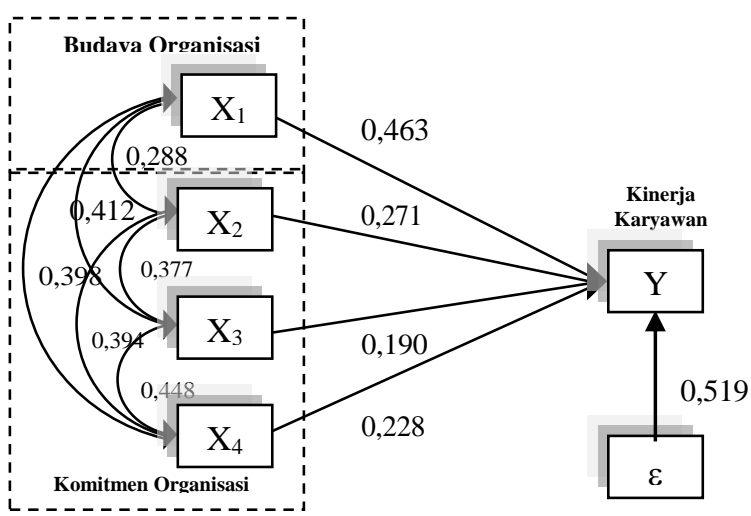

Gambar 4.1 Diagram Jalur Pengaruh Budaya organisasi dan komitmen organisasi Terhadap Kinerja karyawan

Dari hasil perhitungan, diperoleh koefisien jalur untuk Budaya organisasi dan komitmen organisasi terhadap kinerja karyawan yang tersajikan dalam gambar dan model struktural di atas. Budaya organisasi memiliki koefisien jalur sebesar 0,463, sedangkan komitmen organisasi yang dijelaskan dari ketiga sub variabelnya yaitu komitmen afektif dengan koefisien jalur sebesar 0,271, komitmen kontinuens dengan koefisien jalur sebesar 0,190, dan komitmen normatif dengan koefisien jalur sebesar 0,228.

Berikut disajikan hasil akumulasi pengaruh budaya organisasi dan komitmen organisasi terhadap kinerja karyawan.

Tabel 4.4. Akumulasi Pengaruh Dari Budaya Organisasi dan Komitmen Organisasi Terhadap kinerja karyawan

\begin{tabular}{|l|c|}
\hline \multicolumn{1}{|c|}{ Dimensi } & $\begin{array}{c}\text { Pengaruh Total } \\
\text { Terhadap kinerja } \\
\text { karyawan Pada } \\
(\%)\end{array}$ \\
\hline Budaya organisasi $\left(\mathrm{X}_{1}\right)$ & 32,839 \\
\hline Komitmen organisasi & 40,246 \\
\hline - Komitmen Afektif $\left(\mathrm{X}_{2}\right)$ & 15,327 \\
\hline - Komitmen Kontinuens $\left(\mathrm{X}_{3}\right)$ & 11,124 \\
\hline - Komitmen Normatif $\left(\mathrm{X}_{4}\right)$ & 13,795 \\
\hline $\begin{array}{l}\text { Total Pengaruh dari Budaya } \\
\text { Organisasi dan Komiten Organisasi }\end{array}$ & 73,085 \\
\hline Pengaruh variabel lain & 26,915 \\
\hline
\end{tabular}




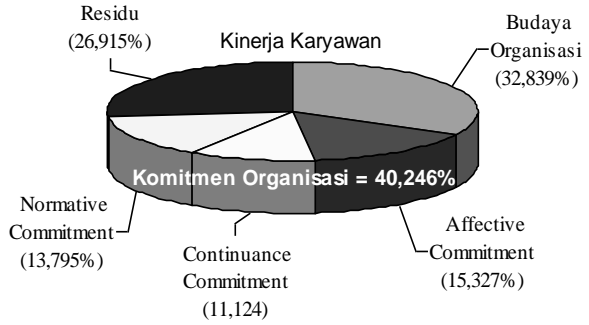

Total Pengaruh dari Budaya Organisasi dan Komitemen Organisasi terhadap Kinerja Karyawan sebesar 73,083\%

Hasil perhitungan analisis jalur menunjukkan adanya pengaruh dari budaya organisasi dan komitmen organisasi melalui ketiga sub variabelnya yaitu komitmen afektif, komitmen kontinuens, komitmen normatif terhadap kinerja karyawan pada PT. Pelayaran Samudera Selatan Jakarta dengan total pengaruh dari semua variabel terhadap kinerja karyawan sebesar $70,085 \%$ dan pengaruh variabel lain yang tidak terlibat dalam penelitain ini sebesar 26,915\%. Dari hasil perhitungan dapat diketahui bahwa komitmen organisasi memiliki total pengaruh paling besar terhadap kinerja karyawan dengan total pengaruh sebesar $40,246 \%$ dimana disumbangkan paling besar oleh sub variabel komitmen afektif .

Hasil penelitian menunjukkan pengaruh positif dari budaya organisasi terhadap kinerja karyawan. Penelitian ini mendukung pendapat McShane dan Glinow (2003) yang mengemukakan bahwa budaya perusahaan merupakan nilai-nilai sosial yang makin penting untuk memperoleh staf baru dan karyawan dengan kinerja tertinggi.

Penelitian ini juga mendukung pendapat Robbins yang menjelaskan bahwa budaya organisasi dibentuk dari suatu persepsi subyekif dari karyawan secara keseluruhan berdasarkan pada faktor-faktor seperti toleransi resiko, tekanan pada tim dan dukungan orang. Sebenarnya persepsi keseluruhan ini menjadi budaya atau kepribadian organisasi tersebut. Persepsi yang mendukung atau tidak mendukung ini kemudian mempengaruhi kinerja dan kepuasan kerja karyawan dengan dampak yang lebih besar pada budaya yang lebih kuat (Robbins, 2001: 528).

Penelitian ini juga menemukan pengaruh positif komitmen organisasi terhadap kinerja karyawan sebesar 40,246\%. Temuan ini mendukung pendapat yang dikemukakan oleh Luthans (2002), yang mengemukakan bahwa baik penelitian terdahulu maupun terkini, mendukung hubungan positif antara komitmen organisasi dan keluaran yang diharapkan, seperti kinerja yang tinggi, turnover yang rendah dan tingkat absensi yang rendah.

Berdasarkan hasil penelitian, maka hipotesis yang diajukan yaitu: "Budaya organisasi dan komitmen organisasi baik secara parsial maupun simultan berpengaruh terhadap kinerja karyawan" terbukti.

\section{IMPLIKASI MANAJERIAL}

Schein (2002) mengatakan bahwa sekarang ini budaya organisasi memiliki arti yang lebih penting dibandingkan dahulu. Meningkatnya iklim kompetisi, globalisasi, merjer, akuisisi, aliansi, dan perkembangan dunia pekerjaan yang bervariasi.

Berbagai pendapat dari para ahli perilaku keorganisasian mengemukakan betapa pentingnya perusahaan melakukan pengelolaan yang efektif terhadap budaya organisasi. Nilai-nilai perusahaan menjadi hal yang sangat penting karena merupakan pedoman karyawan dalam bertingkah laku di perusahaan.

Hasil penelitian pada PT Pelayaran Samudera Selatan menunjukkan bahwa budaya perusahaan belum sepenuhnya berjalan dengan optimal. Dukungan perusahaan terhadap inivasi dan pengambilan resiko belum berjalan dengan optimal, hal ini ditunjukkan dengan angka rasio sebesar 67,5 persen.

Stabilitas perusahaan masih belum berjalan optimal, hal ini terutama ditimbulkan dengan tingginya angka turnover. Tingkat perputaran karyawan yang tinggi menunjukkan stabilitas perusahaan kurang optimal.

Berdasarkan kenyataan tersebut, hendaknya perusahaan meningkatkan karakteristik budaya efektifnya, terutama untuk kedua indikator diatas. Hal ini perlu dilakukan mengingat budaya perusahaan memiliku kaitan dan pengaruh positif dan signifikan terhadap kinerja karyawan.

Perusahaan juga hendaknya melakukan pemantauan yang kontinyu terhadap komitmen dari karyawannya. Semakin baik pemantauan terhadap komitmen karyawan, maka akan semakin tepat karyawan menakar seberapa besar komitmen karyawan terhadapa organisasi. 
Penelitian ini menunjukkan begitu besarnya pengaruh komitmen organisasi terhadap tingkat kinerja karyawan, Penelitian menunjukkan hubungan yang positif antara kedua variable komitmen dengan kinerja, yang berarti bahwa semakin besar komitmen karyawan terhadap perusahaan maka akan semakin tinggi kinerja yang ditunjukkan o;eh karyawan.

\section{KESIMPULAN}

Berdasarkan hasil penelitian dan pembahasan, penulis mencoba menyajikan kesimpulan sebagai berikut:

Akumulasi dari seluruh dimensi secara umum menunjukkan bahwa penilaian terhadap budaya organisasi PT Pelayaran Samudera selatan berada pada kategori baik dengan angka sebesar $71,1 \%$. Dengan demikian dapat dikatakan bahwa budaya organisasi perusahaan selama ini berada pada kondisi baik. Walaupun demikian masih terdapat dua dimensi budaya organisasi, yaitu inovasi dan pengambilan resiko serta stabilitas yang termasuk pada kategori sedang. Hal ini menunjukkan bahwa kedua dimensi ini belum berlangsung secara optimal di perusahaan.

Adapun komitmen pegawai terhadap perusahaan berada pada kategori tinggi. Hal ini menunjukkan bahwa komitmen karyawan terhadap organisasi sudah baik. Namun demikian kalau dilihat dari perolehan skor, hanya sedikit terpaut diatas kategori sedang. Dimensi komitmen normatif berada pada skor paling tinggi, artinya karyawan memiliki komitmen ke perusahaan karena memang sudah seharusnya

Berdasarkan hasil akumulasi tanggapan responden diperoleh informasi bahwa kondisi kinerja karyawan pada PT Pelayaran Samudera Selatan berada pada kategori tinggi dengan angka akumulasi sebesar 70,6\%. Hal ini menunjukkan bahwa selama ini kinerja karyawan sudah cukup baik walaupun masih terdapat beberapa kekurangan. Dimensi kuantitas dan ketepatan waktu mendapaykan skor terendah, hal ini menunjukkan kedua dimensi ini belum sepenuhnya optimal. Bahkan untuk dimensi kuantitas masih termasuk pada kategori sedang.

Hasil perhitungan analisis jalur menunjukkan bahwa terdapat pengaruh Budaya organisasi dan komitmen organisasi (sub variabelnya yaitu komitmen afektif, komitmen kontinuens dan komitmen normatif) terhadap kinerja karyawan pada PT. Pelayaran Samudera Selatan Jakarta dengan total pengaruh dari semua variabel terhadap kinerja karyawan sebesar $70,085 \%$ dan pengaruh variabel lain yang tidak terlibat dalam penelitain ini sebesar 26,915\%. Dari hasil perhitungan dapat diketahui bahwa komitmen organisasi memiliki total pengaruh paling besar terhadap kinerja karyawan dengan total pengaruh sebesar 40,246\% dimana disumbangkan paling besar oleh sub variabel komitmen afektif.

\section{DAFTAR PUSTAKA}

Bernardin H, John dan E.A. Russel. 1998. Human Resources Management: An Experiental Approach. New York: McGraw-Hill Inc

Kreitner, R., \& Angelo Kinicki. 2001. Organizational Behavior. Fifth Edition. Mc.Graw-Hill. Companies Inc. New York.

Luthans, F, 2002, Organizational Behavior, 9th Edition, McGraw-Hill, New York.

Masri Singarimbun \& Sofyan Effendi, 1995. Metode Penelitian Survei. Jakarta: LP3S

Moh. Nazir, 1988. Metode Penelitian. Ghalia Indonesia, Jakarta.

Mc. Shane, Steven L \& Mary Ann Von Glinow. 2003. Organizational Behavior, Second Edition. New York : McGraw-Hill.

Robbins, S. P., 2001. Organizational Behavior,. Ninth Edition, Prentice Hall, Upper Saddle River, New Jersey.

Schein, E., H., 2002. Organizational Culture and Leadership, Second Edition, Jossey Bass, A wiley Company, New York.

Stoner, James AF at al. 1995. Management. New Jersey: A Simon \&Schuster Company

Sugiyono. 1999. Methode Penelitian Administrasi. Bandung : Alfabeta.

Wheelen, Thomas L. \& J. David Hunger. 2002. Strategic Management and Business Policy. Eight edition. Prentice Hall. New Jersey.

Werther, William B. \& Davis, Keith. 1996. Human Resources And Personnel Managemen. Fifth Edition. Mc Graw Hill. Inc. Singapora. 